\title{
IMPROVING STUDENTS' PRONUNCIATION THROUGH TELL ME MORE PRONUNCIATION SOFTWARE
}

\author{
Trivania Ayulistya \\ Department of English Education, University of Kuningan \\ Email: trivaniaayulistya@yahoo.co.id
}

APA Citation: Ayulistya, T. (2016). Improving students' pronunciation through Tell Me More pronunciation software. Indonesian EFL Journal, 2(2), 110-116

Abstract: This research aims at finding out whether using Tell Me More software as media can improve students' pronunciation at tenth grader in Vocational High School Karya Nasional Kuningan. Pre-experimental design was employed in this research to test the objective theories. Pre-test, post-test and questionnaire were used to collect the data. The data were analyzed by using SPSS 20.0. The t-test result was 0.000 . It means that it was lower than $0.05(0.000<0.05)$ so that the null hypothesis is rejected and alternative hypothesis is accepted. Besides, the mean scores of pre-test and post-test in pre-experimental class were significantly different $(4,09$ up to 6,02$)$. To confirm the result of this research, questionnaires were also used to describe students' attitude towards the use of this software in improving their pronunciation. As result, it was found that in affective aspects, there were $63,3 \%$ of the students who agreed with the use of Tell Me More Software as media to improve students' pronunciation. In behavioral aspects, there were $50 \%$ of the students who agreed with the use of Tell Me More Software as media. The last in cognitive aspects, there were 52,5\% of the students who agreed with the use of Tell Me More Software as media. Based on those results, Tell Me More software can be applied by English teachers in teaching pronunciation since this software is effective to improve students' pronunciation.

Keywords: Tell Me More software, pronunciation, students.

\section{INTRODUCTION}

Speaking, as one of four skills in English language learning, is considered as one of the hardest things in learning language. When we taught English, especially in spoken form, we absolutely involved pronunciation because it is the important part of the spoken cycle (Schmitt, 2002).

As stated by Brown (2001), the conversation class is something of an enigma in language teaching. So, there are many problems faced by students in speaking, starting from feeling ashamed and afraid to speak until wondering how to pronounce a word.

Pronunciation is one of the most important aspects in speaking skill since it plays a crucial role in delivering meaning. Because of its importance, Harmer (2007) states that pronunciation is very important and students should pay close attention to pronunciation as early as possible. Harmer (2007) adds that pronunciation teaching does not only make students aware of different sounds and sound feature (and what this mean), but can also improve their speaking immeasurably.

As stated above, it is clear that pronunciation plays a crucial role in delivering meaning, for example when a learner says perfect /'p3:fikt/ and perfect /pə'fekt/. Although the word is the same (perfect), but it has different pronunciation that will then show different meaning. This condition makes 
some students hard to pronounce 'unfamiliar' words correctly. Wrong pronunciation can be caused by a less practice done by the students or the teacher rarely gives them a pronunciation practice in the classroom. As stated by Kelly (2000), reflection of learners' pronunciation errors and how these can inhibit successful communication is a useful basis on which to assess why it is important to deal with pronunciation in the classroom.

To improve students' pronunciation skill, there are many ways that can be done by the teachers to help their students to improve their pronunciation skill, starting from giving more pronunciation practice in the classroom until using many kinds of media that can be easily found in this modern era. One of the media is pronunciation software. Pronunciation software refers to a device in computer that can be used to help students in pronunciation practice (Levy, 2006).

Tell Me More is virtual language software, used by individuals, language schools, universities, and corporations around the world. It is a kind of pronunciation software used by the researcher in this pre-experimental research. Tell Me More speech recognition technology recognizes what ones say, assesses their pronunciation, and corrects any mistakes. The software constantly analyses the results obtained in each activity and then suggests which activity to do next, following the learner's needs and objectives. This innovative working mode is intended to allow learners to work independently by analyzing their results as they work and by adapting their working program according to these results. The author of Tell Me More is Auralog, Inc. Tell Me More has the strengths and the weaknesses. The strengths are 1) Smoothness of system operation, especially for the video and sound components, worked very well, 2) Variety of activities keeps student interest high, 3) Program works well with Windows XP; microphone/headphones work well, 4) Instructions can be in any of six languages: Dutch, English, French, German, Spanish, or Italian, and the process to change the language is easy, 5) Great deal of repetition of vocabulary words, which enhances acquisition, and 6) Step-by-step instructions are available for each activity.

On the other hand, the weaknesses of Tell Me More are; 1) It is not clear why the topics and their vocabulary were chosen. Some of the students used to test this software wondered if these areas were really the most important for them at an intermediate level, 2) Some of the voices in the listening component are dangerously close to "teacher-use" (however, most of the voices use appropriate native-speaker intonation and speed), and 3) The pronunciation components do not appear to take into consideration variations across dialects (as in American pronunciation of the first two words of 'put your hat on', so that they rhyme with 'butcher').

Having these reasons the researcher was interested in analyzing the use of pronunciation software in improving students' pronunciation skill. The pronunciation software was chosen as a media to improve students' pronunciation skill since it was considered able to make students more interested and enjoy the pronunciation class than only repeating the teacher's sound. Many kinds of pronunciation software were easy to be used for both teacher and students not only in the classroom, but also at home, students can use pronunciation software to improve their pronunciation by themselves. This pronunciation software 
can motivate students to learn more about pronunciation and to improve their pronunciation skill. Thus, the researcher was strongly interested in conducting a research entitled “Improving Students' Pronunciation through Tell Me More Pronunciation Software: A Pre-Experimental Research at Tenth Grader of Vocational High School Karya Nasional Kuningan."

\section{METHOD}

This research adapted a quantitative approach by using preexperimental design. To collect the data, the researcher used tests that consisted of pre-test and post-test, and questionnaire. The pre-test is given to pre-experimental class before the treatment. The test is in the form of pronunciation practice. Here, the 20 students (8 females and 12 males) are asked to pronounce 20 vocabularies relating to Describing Object (big /big/,

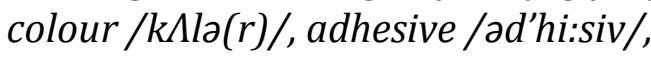
etc.). The researcher uses microphone/headset to listen students' pronunciation and analyses it by using Tell Me More pronunciation software to assess students' pronunciation. The post-test is given to pre-experimental class after the treatment to know the improvement of students' pronunciation skill. The result of post-test is then compared to the result of pre-test. Basically, pre-test and post-test instruments are the same form when the 20 students ( 8 females and 12 males) were asked to pronounce 20 vocabularies relating to Describing Object (big /big/, colour $/ k \Lambda l a(r) /$, adhesive /ad'hi:siv/, etc.).

To explore student's attitude towards the use of Tell Me More pronunciation software, the researcher uses questionnaire. The questionnaire is in the form of Likert Scale promoted by Fraenkel and Wallen (2009). "Likert scale consists of a set statements to which an individual responds. Subjects checklist the word or number that best represents how they feel about the topics included in the questions or statements in the scale" (Fraenkel and Wallen, 2009, p.124). Five criteria of Likert Scale by Fraenkel and Wallen (2009) can be seen in the following table.

Table 1. Criteria of Likert Scale by Fraenkel and Wallen (2009, p.126)

\begin{tabular}{|l|l|c|}
\hline \multicolumn{1}{|c|}{ No. } & \multicolumn{1}{|c|}{ Criteria } & Score \\
\hline 1. & Strongly Agree (SS: sangat setuju) & 5 \\
\hline 2. & Agree (S: setuju) & 4 \\
\hline 3. & Undecided / neither agree nor disagree (R: ragu-ragu) & 3 \\
\hline 4. & Disagree (TS: tidak setuju) & 2 \\
\hline 5. & Strongly Disagree (STS: Sangat Tidak Setuju) & 1 \\
\hline
\end{tabular}

Furthermore, in administering questionnaire, the researcher uses attitude theory from Oscamp and Schultz (2005). The questionnaire used in this research has been tried for its validity and reliability.

To analyze the collected data, the researcher used SPSS 20.0 in testing the normality, homogeneity, and dependent t-test. Then, to count the questionnaire of students' attitude percentage after being taught by using Tell Me More pronunciation software as media, the researcher counted it manually.

\section{RESULTS AND DISCUSSION}

The requisite of conducting t-test is that the data should be normal, and homogeneous, so that the normality and homogeneity of pretest and posttest 


\section{Trivania Ayulistya}

Improving Students' Pronunciation through Tell Me More Pronunciation Software

were done before doing t-test in this research. Normality distribution test was done to investigate whether the distribution of pretest and posttest scores in two groups are normally distributed or not. The criterion of normal distribution is when the probability is higher than the level of significance 0.05 ( $p>0.05)$. The hypotheses to conduct this normality test are stated below.

$\mathrm{H}_{0}$ : the score of pre-test and post-test are normally distributed ( $\mathrm{p}>0.05)$ $\mathrm{H}_{\mathrm{a}}$ : the score of pre-test and post-test are not normally distributed $(\mathrm{p}<0.05)$

Table 2. Tests of Normality

\begin{tabular}{|c|c|c|c|c|c|c|c|}
\hline & \multirow[t]{2}{*}{ Tests } & \multicolumn{3}{|c|}{ Kolmogorov-Smirnova } & \multicolumn{3}{|c|}{ Shapiro-Wilk } \\
\hline & & Statistic & $\mathrm{df}$ & Sig. & $\begin{array}{l}\text { Statisti } \\
\text { c }\end{array}$ & $\mathrm{df}$ & Sig. \\
\hline \multirow{2}{*}{$\begin{array}{l}\text { Students' score of } \\
\text { Pretest and Posttest }\end{array}$} & Pretest & .182 & 20 & .081 & .817 & 20 & .002 \\
\hline & Posttest & .196 & 20 & .052 & .900 & 20 & .041 \\
\hline
\end{tabular}

Table 2 shows that the data on pre-test and post-test are normally distributed. It can be seen from the Sig. score of pre-test that is higher than the level of significance $(0.081>0.05)$. Besides, the Sig. score of the post-test is also higher than the level of significance $(0.052>0.05)$. So, it can be concluded that the null hypothesis is accepted which means that the score of pre-test and post-test are normally distributed.

Then, homogeneity of variance test was conducted to illustrate the t-test procedure that can be used to examine the hypothesis. The level of significance is 0.05 , and the asymp.sig $>0.05$. The hypotheses of this homogeneity variance test are stated below.

$\mathrm{H}_{0}$ : the data of variance of pre-test and post-test are homogeneous

(asymp.sig $>0.05$ )

$\mathrm{H}_{\mathrm{a}}$ : the data of variance of pre-test and post-test are not homogeneous (asymp.sig<0.05)

Table 3. Test of Homogeneity of Variances

\begin{tabular}{|r|r|r|c|}
\hline Lavene statistic & df1 & df2 & \multicolumn{1}{c|}{ Sig. } \\
\hline .120 & 1 & 38 & .731 \\
\hline
\end{tabular}

Based on Table 3, it was clear that the significance of homogeneity of variance test is 0.731 and it is higher than 0.05 . It means that the data of pretest and posttest on pre-experimental class are homogeneous, so that the null hypothesis is accepted and t-test can be done.

After knowing that the data were normal and homogeneous, t-test can be conducted. As the result, it was found that students' pronunciation in the preexperimental class before and after receiving the treatment were significantly different. It was seen from the result of dependent test bellow.

$\mathrm{H}_{0}$ : there is no significant difference of means between pre-test and posttest (sig. 2 talied $>0.05$ )

$\mathrm{H}_{\mathrm{a}}$ : there is significant difference of means between pre-test and posttest (sig. 2 talied<0.05) 
Table 4. Paired Samples Statistics

\begin{tabular}{|ll|r|r|r|r|}
\hline & & \multicolumn{1}{|c|}{ Mean } & \multicolumn{1}{c|}{$\mathrm{N}$} & \multicolumn{1}{c|}{ Std. Deviation } & \multicolumn{2}{|c|}{ Std. Error Mean } \\
\hline \multirow{2}{*}{ Pair 1 } & Before & 4.09 & 20 & .326 & .073 \\
& After & 6.02 & 20 & .304 & .068 \\
\hline
\end{tabular}

Table 5. Paired Samples Test

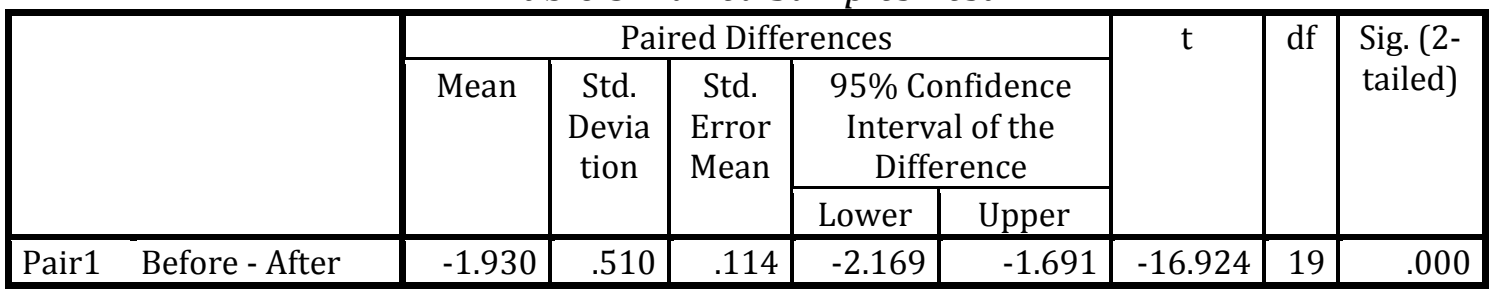

Table 4 above shows that the mean of students improved after they received the treatment. It can be seen from the mean on pre-test that is 4.09 before receiving the treatment, while the students' mean on post-test improved becomes 6.02 after receiving the treatment $(6.02>4.09)$.

Then, based on the table 5 , the $\operatorname{sig}(2$-tailed) value is lower than the significance level $(0.000<0.05)$. This means that the null hypothesis is rejected and alternative hypothesis is accepted which means that there is significant difference of means between pre-test and post-test in preexperimental class. In other words, it can be concluded that Tell Me More Software can improve students' pronunciation skill.

\section{Students' attitude towards the use of pronunciation software to improve their pronunciation}

To know students' attitude towards the use of Tell Me More pronunciation software to improve their pronunciation skill, the researcher used questionnaire. This questionnaire was examined for the validity and reliability before it is used. As result, it was proved that all item of the questionnaire were valid as examined by using Pearson Coefficient Correlation. The validity is got by comparing $r_{x y}$ and $r_{\text {table. If }} r_{x y}$ is higher than rtable, the item is valid.

Table 6. The Result of Validity Test of Questionnaire

\begin{tabular}{|c|c|c|c|}
\hline N0 & $\mathrm{r}_{\mathrm{xy}}$ & $\mathrm{r}_{\text {table }}$ & Validity \\
\hline 1 & 0.482 & 0.444 & Valid \\
\hline 2 & 0.468 & 0.444 & Valid \\
\hline 3 & 0.603 & 0.444 & Valid \\
\hline 4 & 0.788 & 0.444 & Valid \\
\hline 5 & 0.701 & 0.444 & Valid \\
\hline 6 & 0.522 & 0.444 & Valid \\
\hline 7 & 0.600 & 0.444 & Valid \\
\hline 8 & 0.667 & 0.444 & Valid \\
\hline 9 & 0.759 & 0.444 & Valid \\
\hline 10 & 0.789 & 0.444 & Valid \\
\hline
\end{tabular}

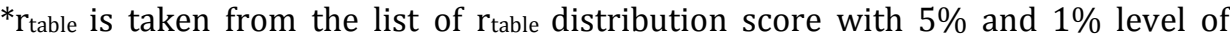
significance. 
Table 6 above shows the coefficient correlation $\left(r_{x y}\right), r_{\text {table }}$ and the status of validity. The status of validity is gained by comparing $r_{x y}$ and $r_{\text {table. . If }} r_{x y}$ is higher than $r$ table, the item is valid. But, if $r_{x y}$ is lower than $r_{\text {table, the item is not }}$ valid. Thus, as it can be seen on the table above, all items of the questionnaire used in this research are valid because $r_{x y}>$ rtable.

In addition, reliability test was also conducted to know whether or not the questionnaire used in this research is reliable.

Table 7. Reliability Statistics

\begin{tabular}{|r|r|}
\hline Cronbach's Alpha & N of Items \\
\hline 839 & 10 \\
\hline
\end{tabular}

Based on the table above, it can be seen that the score of Cronbach Alpha as reliability test of the questionnaire is 0.839 . This score is higher than 0.70 , so it can be concluded that the list of questionnaire used in this research is reliable.

By the result of validity and reliability above, the researcher concluded that the list of questionnaire used in this research was valid and reliable. As stated previously that questionnaire was used to describe students' attitude towards the use of Tell Me More as media to improve students' pronunciation skill. The result of the questionnaire is presented in the following table:

Table 8. The Result of Questionnaire

\begin{tabular}{|l|c|c|c|c|c|}
\hline \multirow{2}{*}{$\begin{array}{l}\text { Attitude } \\
\text { Component }\end{array}$} & $\begin{array}{c}\text { Strongly } \\
\text { Agree (5) }\end{array}$ & Agree(4) & Undecided(3) & Disagree(2) & $\begin{array}{c}\text { Strongly } \\
\text { Disagree (1) }\end{array}$ \\
\hline Affective & $21.6 \%$ & $63.3 \%$ & $15 \%$ & - & - \\
\hline Behavioral & $10 \%$ & $50 \%$ & $33.3 \%$ & $6.7 \%$ & - \\
\hline Cognitive & $16.2 \%$ & $52.5 \%$ & $30 \%$ & $1.3 \%$ & - \\
\hline
\end{tabular}

Based on the table above, attitude component especially in affective aspect shows that most of the students agree with the statements as many as $63,3 \%$. In behavioral aspect, $50 \%$ of the students agree with the statements given. Then, cognitive aspect shows that $52,5 \%$ of the students agree with the statements.

\section{CONCLUSION}

This research concerns on improving students' pronunciation through Tell Me More pronunciation software. This research formulates two research questions; whether or not Tell Me More pronunciation software able to improve students' pronunciation skill, and what students' attitude towards the use of Tell Me More pronunciation software.

To find out whether or not Tell Me More pronunciation software able to improve students' pronunciation skill, the researcher conducts tests (pre-test and post-test). The data from the test were then calculated by using SPSS. It purposes to find out the students' pronunciation skill improvement by using Tell Me More. As result, it was found that there is a significant improvement between pre-test and posttest score on pre-experimental class in which the mean score on pretest is $\mathbf{4 . 0 9}$ and the post-test score is $\mathbf{6 . 0 2}$. Besides, the result of dependent $t$-test shows that the significance value is $\mathbf{0 . 0 0 0}$ 
$(\mathbf{0 . 0 0 0}<\mathbf{0 . 0 5 )}$. It means that the null hypothesis is rejected and alternative hypothesis is accepted.

Then, regarding the students' attitudes towards the use of Tell Me More pronunciation software in improving their pronunciation skill, the results of the questionnaire analysis shows that $\mathbf{6 3 , 3 \%}$ students in affective aspect, $50 \%$ students in behavioural aspect, $\mathbf{5 2 , 5 \%}$ in cognitive aspect agree with the statements. It can be concluded that the students give positive attitude towards the use of Tell Me More in improving their pronunciation skill.

Thus, it can be concluded that the students' pronunciation skill improves significantly. It is seen from the mean score of the students on posttest that is better than the mean score before Tell Me More are applied. Besides, most of the students showed positive attitudes towards the use of Tell Me More as media in teaching pronunciation that can help them to improve their pronunciation skill.

\section{REFERENCES}

Brown, H. D. (2001). Teaching by principles: An interactive approach to language pedagogy. Englewood Cliffs: Prentice Hall.

Fraenkel, J. R., \& Wallen, N. E. (2009). How to design and evaluate research in education (7th ed.). New York: McGraw Hill Company, Inc.

Harmer, J. (2007). The practice of English language teaching ( $\left.4^{\text {th }} \mathrm{ed}\right)$. Cambridge: Pearson Education Limited.

Kelly, G. (2000). How to teach pronunciation. Cambridge: Pearson Education Limited.

Levy, M., \& Stockwell, G. (2006).Call dimensions: Option and issues in computer-assisted language learning. Mahwah: Lawrence Erlbaum Associates Inc.

Oscamp, S., \& Schultz, P. W. (2005). Attitudes and opinions ( $3^{\text {rdede. }}$.). London: Lawrence Erlbaum Associates Publisher.

Schmitt, N. (2002). An introduction to applied linguistics. London: Oxford University Press. 